\title{
Production of chromophoric dissolved organic matter (CDOM) in the open ocean by zooplankton and the colonial cyanobacterium Trichodesmium spp.
}

\author{
Deborah K. Steinberg ${ }^{1, *}$, Norman B. Nelson ${ }^{2}$, Craig A. Carlson ${ }^{3}$, Anne C. Prusak ${ }^{4}$ \\ ${ }^{1}$ Department of Biological Sciences, Virginia Institute of Marine Science, PO Box 1346, Route 1208 Greate Road, Gloucester Point, \\ Virginia 23062, USA \\ ${ }^{2}$ Institute for Computational Earth System Science, and ${ }^{3}$ Department of Ecology, Evolution, and Marine Biology, University \\ of California Santa Barbara, Santa Barbara, California 93106, USA \\ ${ }^{4}$ School of Biology, Georgia Institute of Technology, 311 Ferst Drive, Atlanta, Georgia 30332, USA
}

\begin{abstract}
Chromophoric (or colored) dissolved organic matter (CDOM) has been identified as a major determinant of the optical properties of oligotrophic oceans. The factors controlling distribution of CDOM far from the direct influence of land are not well known, as CDOM abundance and distribution does not directly correlate with phytoplankton productivity or biomass, or with dissolved organic matter (DOM) concentration. As part of a larger study of the dynamics of CDOM in the open ocean, we investigated direct release from plankton as a factor contributing to distribution patterns of CDOM. We measured the production of CDOM by zooplankton (copepods, euphausiids, amphipods, salps, polychaetes), protozoans (colonial radiolaria), and by the colonial cyanobacterium Trichodesmium spp. in the North Atlantic subtropical gyre. Groups of individual species of plankton were incubated and absorption spectra were obtained for their release products. CDOM was produced by all organisms examined, and absorption spectra varied by taxa, with major taxa exhibiting characteristic absorption peaks. Plankton-produced DOM is a source of labile carbon and thus facilitates microbial activity, and CDOM may also serve as photoprotection for near-surface-living organisms. Zooplankton likely play an important role in the CDOM cycle in the Sargasso Sea, directly through release/excretion of CDOM and indirectly by providing a labile substrate (excretia) for microbial-mediated production of CDOM.
\end{abstract}

KEY WORDS: Zooplankton - Trichodesmium - Chromophoric dissolved organic matter - CDOM · Excretion $\cdot$ Sargasso Sea $\cdot$ North Atlantic

Resale or republication not permitted without written consent of the publisher

\section{INTRODUCTION}

The optically active fraction of dissolved organic matter, known as CDOM (chromophoric dissolved organic matter), plays a major role in determining underwater light availability in the open ocean, and can influence the accuracy of global satellite-based measurements of ocean chlorophyll and primary productivity (Nelson \& Siegel 2002). CDOM is also thought to play an important role in climate-related biogeochemical cycles (Mopper \& Kieber 2002), and can be a source of labile carbon, which facilitates microbial productivity when bleached by sunlight (e.g Kieber et al. 1990, Mopper et al. 1991, Nelson et al. in press). Operationally, CDOM is defined as organic substances that absorb ultraviolet (UV) or visible light and pass through a submicrometer filter (usually $0.2 \mu \mathrm{m})$ (Nelson \& Siegel 2002). CDOM concentrations in the open ocean (absorption coefficient at $325 \mathrm{~nm}$ typically 0.05 to $0.25 \mathrm{~m}^{-1}$, Nelson \& Siegel 2002) are thought to reflect local production and destruction processes, as only a small fraction of open-ocean DOM derives from terrestrial sources (Hedges et al. 1997, Opsahl \& Benner 1997). 
However, little is known of the local sources and sinks of CDOM in the open sea. At the US JGOFS Bermuda Atlantic Time-series Study (BATS) station in the subtropical Sargasso Sea, CDOM distribution does not directly correlate with phytoplankton productivity or biomass on a seasonal scale (Siegel et al. 1995, Siegel \& Michaels 1996, Nelson et al. 1998), or with dissolved organic carbon concentration (DOC) (Siegel \& Michaels 1996, Nelson et al. 1998). Recently, Nelson et al. (in press) found that CDOM is produced by naturally occurring bacterial assemblages in the Sargasso Sea, and that the quality of the DOM growth substrate plays an important role in net CDOM production. This suggests a local origin and significant dynamics for CDOM cycling in the open sea. A number of biological processes can regulate the concentration of CDOM in the water column, including phytoplankton release, products of zooplankton grazing, bacterial release and uptake, and viral interactions (Nelson \& Siegel 2002). However, there are few quantitative data regarding biological controls of CDOM cycling. As part of a larger study of the dynamics of CDOM in the open ocean, we investigated direct release of CDOM by a variety of plankton taxa as a contributing factor to distribution patterns of CDOM.

Zooplankton produce DOM through sloppy feeding (Dagg 1974, Lampert 1978, Jumars et al. 1989), excretion (e.g. Nagata \& Kirchman 1992, Steinberg et al. 2000, 2002), and fecal pellet dissolution (Urban-Rich 1999). Zooplankton excretion of DOM has recently been recognized as an important component of zooplankton metabolism, although there are relatively few studies of excretion of DOM by zooplankton (Steinberg et al. 2002). Gelatinous zooplankton such as medusae (Hansson \& Norrman 1995) or polychaetes (Steinberg et al. 2000, 2002) may also release DOM via mucus production. Even less is known about the chemical composition of zooplankton-produced DOM, although a portion of this DOM is thought to be highly labile and a good substrate for bacterial metabolism. In addition, while the importance of cryptic and conspicuous coloration (or transparency) of zooplankton is well known in pelagic ecosystems (e.g. Herring 1967, McFall-Ngai 1990), and the inherent optical properties of some zooplankton have been studied (Johnsen 2000, Johnsen \& Widder 2001), few data exist with regard to the optical properties of their excretion products (organic or inorganic), which may absorb UV radiation and play a role in photoprotection.

We measured the production of CDOM by zooplankton (copepods, euphausiids, amphipods, salps, polychaetes), protozoans (colonial radiolaria), and the colonial cyanobacterium Trichodesmium spp. at several sites in the North Atlantic subtropical gyre. CDOM was produced by all organisms examined, and absorp- tion spectra varied by taxa, with characteristic absorption peaks correlated to the major taxa. We discuss the possible role and consequences of plankton production of CDOM, such as its use as a substrate for bacterial metabolism, as well as how zooplankton production of CDOM affects CDOM cycling and distribution in the Sargasso Sea.

\section{MATERIALS AND METHODS}

Plankton collection. Plankton were collected at several open-ocean sites in the North Atlantic subtropical gyre (Table 1). Collection sites included the BATS station $\left(31^{\circ} 50^{\prime} \mathrm{N}, 64^{\circ} 10^{\prime} \mathrm{W}\right)$ and Hydrostation $\mathrm{S}$ $\left(32^{\circ} 10^{\prime} \mathrm{N}, 64^{\circ} 30^{\prime} \mathrm{W}\right)$ in the Sargasso Sea, southeast of the island of Bermuda, and a station $190 \mathrm{~km}$ north of Bermuda $\left(34^{\circ} 34^{\prime} \mathrm{N}, 64^{\circ} 15^{\prime} \mathrm{W}\right)$, all visitied between June and October 2000. Additional collections were made along a meridional transect south from the BATS station to $25^{\circ} 00^{\prime} \mathrm{N}, 64^{\circ} 10^{\prime} \mathrm{W}$ in August 2001. Tows were performed from 0 to $200 \mathrm{~m}$ during the day and night with a 2 m diameter, $500 \mu \mathrm{m}$-mesh plankton net. The net was equipped with a large-volume, 'live codend' designed so that water filters out the top of the cod end (Reeve 1980), thus maintaining the organisms in excellent condition (Steinberg et al. 2000, 2002). Colonies of both Trichodesmium spp. and some copepods living near to the surface (e.g. Clausocalanus spp.), were collected in short, $<10 \mathrm{~m}$ drift tows with a $1 \mathrm{~m}$ diameter, $350 \mu \mathrm{m}$-mesh plankton net, also equipped with a similar style non-filtering cod-end. Colonial radiolaria were collected by hand in clean, wide-mouthed polycarbonate jars while snorkeling in surface waters.

Incubations. Plankton were immediately sorted from tows, and healthy active organisms were gently removed by pipette and placed into experimental bottles filled with $1 \mathrm{l}$ of $0.2 \mu \mathrm{m}$ filtered seawater (FSW), prepared by filtering water taken from a conductivity temperature depth (CTD) cast prior to the net tows through a $0.2 \mu \mathrm{m}, 147 \mathrm{~mm}$, Osmonics gravity filter. The number of each species per bottle depended on their size and ranged from 2 for salps and alciopid worms to 200 for small copepod species, and 300 colonies $1^{-1}$ for Trichodesmium spp. All incubations were carried out in acid-cleaned 11 polycarbonate bottles. One or 2 bottles per species and 2 controls (without organisms) were incubated in the dark, normally for $8 \mathrm{~h}$, at in situ sea-surface temperatures $\left(21\right.$ to $\left.28^{\circ} \mathrm{C}\right)$.

Two types of controls were run: 1 with $0.2 \mu \mathrm{m} \mathrm{FSW,}$ and 1 with FSW and water from the tray used to select animals (to ensure that any CDOM signal change in the bottles with animals was due to excretia and not to the water added while transferring the animal). The latter controls were occasionally slightly higher, 
Table 1. Summary of chromophoric (or colored) dissolved organic matter (CDOM) excretion experiments. Temp.: mean incubation temperature. BATS: Bermuda Atlantic Time-series Study. Species for which more than one incubation was conducted are sequentially numbered and correspond to numbered species names in the figures

\begin{tabular}{|c|c|c|c|c|}
\hline Date (dd/mm/yy) & Location & Species & Taxon & Temp. $\left({ }^{\circ} \mathrm{C}\right)$ \\
\hline 08/06/00 & $\begin{array}{l}\text { BATS } \\
31^{\circ} 50^{\prime} \mathrm{N}, 64^{\circ} 10^{\prime} \mathrm{W}\end{array}$ & $\begin{array}{l}\text { Pleuromamma xiphias (1) } \\
\text { Naiades sp. (1) } \\
\text { Salpa fusiformis } \\
\text { Iasis zonaria }\end{array}$ & $\begin{array}{l}\text { Copepod } \\
\text { Alciopid worm } \\
\text { Salp } \\
\text { Salp }\end{array}$ & 21 \\
\hline 21/08/00 & $\begin{array}{l}\text { Hydrostation S } \\
32^{\circ} 10^{\prime} \mathrm{N}, 64^{\circ} 30^{\prime} \mathrm{W}\end{array}$ & $\begin{array}{l}\text { Clausocalanus spp. } \\
\text { Candacia ethiopica } \\
\text { Salpa aspera } \\
\text { Trichodesmium spp. (1) }\end{array}$ & $\begin{array}{l}\text { Copepod } \\
\text { Copepod } \\
\text { Salp } \\
\text { Cyanobacteria }\end{array}$ & 25 \\
\hline 29/09/00 & $34^{\circ} 34^{\prime} \mathrm{N}, 64^{\circ} 15^{\prime} \mathrm{W}$ & $\begin{array}{l}\text { Sapphirina spp. (1) } \\
\text { Trichodesmium spp. (2) }\end{array}$ & $\begin{array}{l}\text { Copepod } \\
\text { Cyanobacteria }\end{array}$ & 24 \\
\hline $30 / 10 / 00$ & $\begin{array}{l}\text { Hydrostation S } \\
32^{\circ} 10^{\prime} \mathrm{N}, 64^{\circ} 30^{\prime} \mathrm{W}\end{array}$ & $\begin{array}{l}\text { Sapphirina spp. (2) } \\
\text { Trichodesmium spp. (3) }\end{array}$ & $\begin{array}{l}\text { Copepod } \\
\text { Cyanobacteria }\end{array}$ & 26 \\
\hline $15 / 08 / 01$ & $\begin{array}{l}\text { Cruise transect south of Bermuda } \\
31^{\circ} 00^{\prime} \mathrm{N}, 64^{\circ} 08^{\prime} \mathrm{S}\end{array}$ & Trichodesmium spp. (4) & Cyanobacteria & 28 \\
\hline 15/08/01 & $31^{\circ} 00^{\prime} \mathrm{N}, 64^{\circ} 08^{\prime} \mathrm{S}$ & Trichodesmium spp. (5) & Cyanobacteria & \\
\hline 16/08/01 & $29^{\circ} 59^{\prime} \mathrm{N}, 64^{\circ} 02^{\prime} \mathrm{S}$ & Mixed euphausiids & Euphausiids & \\
\hline $16 / 08 / 01$ & $29^{\circ} 59^{\prime} \mathrm{N}, 64^{\circ} 02^{\prime} \mathrm{S}$ & Anchyomera blossevillei & Amphipod & \\
\hline $16 / 08 / 01$ & $29^{\circ} 59^{\prime} \mathrm{N}, 64^{\circ} 02^{\prime} \mathrm{S}$ & Naiades sp. (2) & Alciopid worm & \\
\hline $17 / 08 / 01$ & $28^{\circ} 59^{\prime} \mathrm{N}, 64^{\circ} 10^{\prime} \mathrm{S}$ & Colonial radiolaria & Radiolaria & \\
\hline 19/08/01 & $27^{\circ} 57^{\prime} \mathrm{N}, 64^{\circ} 10^{\prime} \mathrm{S}$ & Pleuromamma xiphias (2) & Copepod & \\
\hline
\end{tabular}

an indication that we were adding some CDOM with the animals. Thus, for all experiments, the FSW plus 'tow water' control was subtracted from each of the treatment spectra to obtain actual CDOM absorption values of zooplankton excretia produced over the course of the experiment.

At the end of the incubation, plankton were removed with a $33 \mu \mathrm{m} \mathrm{Nitex}{ }^{\circledR}$ sieve and the sample was filtered through a $0.2 \mu \mathrm{m}$ filter following Nelson et al. (1998) and described briefly here. Samples for CDOM spectroscopy were filtered using an all-glass filtration unit through $0.2 \mu \mathrm{m}$ Nuclepore filters, which had been pre-treated by flushing with $250 \mathrm{ml}$ of Milli-Q water, then $250 \mathrm{ml}$ of $0.2 \mu \mathrm{m}$ FSW. Filtered samples were normally stored for 1 to $2 \mathrm{~d}$ (and no more than $2 \mathrm{wk}$ ), in acid-washed dark-glass bottles (Qorpak) with Teflon (PTFE)-lined lids, in the dark at $4{ }^{\circ} \mathrm{C}$ until spectral analysis. Previous incubation experiments of similar design and duration (Steinberg et al. 2000, 2002) indicated no significant changes in bacterial abundance during experiments.

We did not monitor possible effects of CDOM leaching from fecal pellets defecated during the experiments. Independent studies were conducted to examine the possibility of fecal pellet leaching as a source of CDOM. We collected fecal pellets from salps obtained by SCUBA using hand-held jars. These large pellets were immediately removed from jars containing the salps, incubated (ranging in density from 4 to 127 pellets $\mathrm{l}^{-1}$ ), and processed as described above for excretion experiments. These experiments indicated that absorption of CDOM leached from fecal pellets was insignificant (often immeasurable) compared to CDOM absorption observed in the excretion experiments (data not shown); thus, we assumed CDOM leached from pellets is similarly insignificant compared to CDOM excretion. This same result was found in a comparison of excretion and fecal pellet leaching of DOC (Steinberg et al. 2000). In addition, experiments were conducted in filtered seawater; thus, production of feces was minimal.

Spectral analysis and calculation of CDOM production rate. The absorption spectrum of CDOM was measured with a Perkin-Elmer Lambda 18 Spectrometer scanning from 250 to $750 \mathrm{~nm}$, using a $10 \mathrm{~cm}$, quartz windowed cylindrical cuvette (Nelson et al. 1998). The instrument was zeroed using Milli-Q water in both cuvettes, and all measurements were made with sample and reference at room temperature. The spectra were acquired as decadal optical density, corrected for baseline offsets (e.g. Green \& Blough 1994) and were converted to absorption coefficient $\left(\mathrm{m}^{-1}\right)$ by converting to base e (multiplying by 2.303) and dividing by the geometric path length $(0.1 \mathrm{~m})$. Replicate spectra were measured for each sample, with a mean difference between replicate spectra from all experiments of $3 \%$.

The production rate of CDOM $\left(\mathrm{m}^{2} \mathrm{mg}\right.$ body $\mathrm{C}^{-1} \mathrm{~h}^{-1}$ or $\mathrm{m}^{2} \mathrm{mg}$ colony $\mathrm{C}^{-1} \mathrm{~h}^{-1}$ ) is measured as the increase in the CDOM absorption coefficient $\left(\mathrm{m}^{-1}\right)$ at each wavelength over the course of the experiment, normalized to the density and weight of organisms in the experi- 
ment (mg body $\mathrm{C}$ or mg colony $\mathrm{C} \mathrm{m}^{-3}$ ) and time $\left(\mathrm{h}^{-1}\right)$. Organism weights were either measured in the experiments or obtained from the literature (see table and figure legends for sources).

Ammonia and DOC analysis. Ammonium $\left(\mathrm{NH}_{4}{ }^{+}\right)$ was measured on separate samples by the colorimetric method of Koroleff (1983), using aged, $0.2 \mu \mathrm{m}$-filtered, low-nutrient Sargasso Sea surface water for standard curves and blanks.

DOC samples were analyzed with a custom-built hightemperature combustion (HTC) analyzer designed by the Bermuda Biological Station's DOM research group, or with a Shimadzu TOC-V at the University of California Santa Barbara. The configuration and operating parameters of our custom-built system are described in Hansell \& Carlson (2001). The operating conditions of the Shimadzu TOC-V were slightly modified from the manufacturer's model system. Condensation coils and an internal water trap were removed to reduce the system's dead space. The combustion tube contained Pt pillows on top of Pt alumina beads to improve peak shape and to reduce alteration of combustion matrix throughout the run. $\mathrm{CO}_{2}$-free carrier gas was produced with a Whatman $^{\circledR}$ gas generator. To avoid the small error associated with day-to-day instrument variability, all samples generated from a given experiment were analyzed in a single day's run. All samples were systematically checked against low carbon water and deep Sargasso Sea reference water (2600 m DOC).

Analysis of possible inorganic absorbing compounds. One important consideration is that inorganic compounds in the water or produced by the zooplankton may be absorbing light (erroneously being considered as CDOM), and that the resulting absorption spectra thus may not reflect CDOM produced during

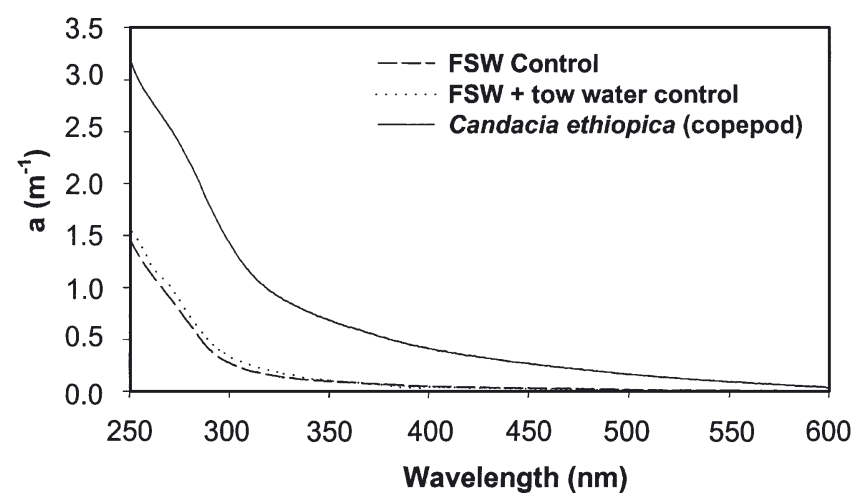

Fig. 1. Example absorption spectra for controls and plankton. Two types of controls were incubated, 1 with $0.2 \mu \mathrm{m}$ filtered seawater (FSW), and 1 with $0.2 \mu \mathrm{m}$ FSW and water pipetted from the tray used to select animals (FSW + tow water), to account for any chromophoric (or colored) dissolved organic matter (CDOM) in the water added with animals during transfer to incubation bottles. a: absorption coefficient the experiment. Hence, we obtained absorption spectra from standard solutions of nitrate $\left(\mathrm{KNO}_{3}: 1 \mathrm{mM}\right)$, nitrite $\left(\mathrm{NaNO}_{2}: 1 \mathrm{mM}\right)$, and ammonium $\left(\mathrm{NH}_{4} \mathrm{Cl}: 10 \mu \mathrm{M}\right.$, $100 \mu \mathrm{M}$, and $1 \mathrm{M}$ ) to compare with absorption spectra and final $\mathrm{NH}_{4}$ concentrations in plankton CDOM excretion/release experiments.

\section{RESULTS}

\section{Production of CDOM}

CDOM was produced by a variety of mesozooplankton taxa as well as by protozoans (colonial radiolaria) and the colonial cyanobacteria Trichodesmium. Absorption spectra from controls were consistently lower than treatments containing animals. A typical example of raw absorption spectra for a copepod (Candacia ethiopica) and corresponding controls for comparison are shown in Fig. 1. The resulting final 'CDOM production spectra' (with control subtracted) for this copepod can be seen in Fig. 2.

Absorption of inorganic compounds in the water or produced by the zooplankton was not a source of error in our experiments. We used filtered surface seawater as an incubation medium. Inorganic $\mathrm{N}$ concentrations are sustained at a level below the limits of detection in the surface waters of the Sargasso Sea during the seasons this work was performed, and never exceed $1 \mu \mathrm{M}$, even during periods of deep winter mixing (Michaels \& Knap 1996, Steinberg et al. 2001). Nitrate and nitrite standards of $1 \mathrm{mM}, 3$ orders of magnitude higher than the highest winter $\mathrm{NO}_{3}+\mathrm{NO}_{2}$ concentration in the Sargasso Sea, were required before an absorption of $>1 \mathrm{~m}^{-1}$ (the values typically seen in our excretion experiments) was detected (data not shown). Thus, ambient concentration of macronutrients did not interfere with optical properties of the incubation media. In addition, the excretion/release of ammonia by animals or Trichodesmium in the experiments (see Table 2 and 'Production of DOC and $\mathrm{NH}_{4}$ ' below) did not reach sufficient concentrations to affect the absorption spectra. The final concentration of ammonia excreted in all experiments ranged between $<1$ and $21 \mu \mathrm{M}$, and the maximum absorption in all experiments ranged between 0.2 and $7.3 \mathrm{~m}^{-1}$. The $100 \mu \mathrm{M}$ ammonia standard had a peak absorption of $0.04 \mathrm{~m}^{-1}$ (data not shown), which would be virtually undetectable in our experiments.

\section{Production of DOC and $\mathrm{NH}_{4}$}

Excretion of dissolved organic carbon (DOC) and ammonia was measured in most experiments in addition to CDOM (Table 2). Rates of DOC excretion for crustaceans 
Table 2. Weight-specific dissolved organic carbon (DOC) and $\mathrm{NH}_{4}$ excretion rates. Species for which $>1$ incubation was conducted correspond to numbered species names in Table 1 and figures. Temp.: mean incubation temperature; -: not available. Animal or colony weight was determined as follows: Sapphirina spp. (0.05 mg C, $0.01 \mathrm{mg} \mathrm{N}$ ind. ${ }^{-1}$; body volume to C, N conversion);

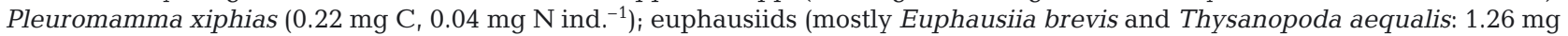

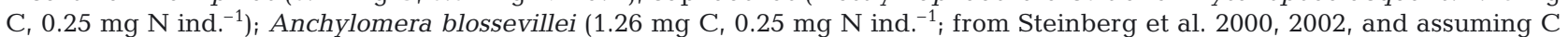
weight $=0.36 \times$ dry weight, $\mathrm{C}: \mathrm{N}=5.1$; Madin et al. 2001); Naiades sp. (3.0 mg C, $0.59 \mathrm{mg} \mathrm{N}$ ind.$^{-1}$; dry weight measured in this experiment and assuming $\mathrm{C}$ weight $=0.36 \times$ dry weight, $\mathrm{C}: \mathrm{N}=5.1$; Madin et al. 2001); colonial radiolaria $(0.1 \mathrm{mg} \mathrm{C}, 0.01 \mathrm{mg} \mathrm{N}$ colony $^{-1}$; from Swanberg 1983, and using C:N = 8.2; Michaels et al. 1995); Trichodesmium spp. (0.011 mg C, $0.002 \mathrm{mg} \mathrm{N}$ colony ${ }^{-1}$; from Carpenter (1983). Excretion rates in parentheses are per colony ( $\mu \mathrm{g} \mathrm{C}$ or $\mathrm{N} \mathrm{colony}^{-1} \mathrm{~h}^{-1}$ )

\begin{tabular}{|c|c|c|c|c|}
\hline $\begin{array}{l}\text { Date } \\
(\mathrm{dd} / \mathrm{mm} / \mathrm{yy})\end{array}$ & $\begin{array}{l}\text { Temp. } \\
\left({ }^{\circ} \mathrm{C}\right)\end{array}$ & Species & $\begin{array}{c}\text { DOC excretion } \\
\left(\mu \mathrm{g} \mathrm{C} \mathrm{mg} \mathrm{C}^{-1} \text { or colony }{ }^{-1} \mathrm{~h}^{-1}\right)\end{array}$ & $\begin{array}{c}\mathrm{NH}_{4} \text { excretion } \\
\left(\mu \mathrm{g} \mathrm{N} \mathrm{mg} \mathrm{\textrm {N } ^ { - 1 }} \text { or colony }{ }^{-1} \mathrm{~h}^{-1}\right)\end{array}$ \\
\hline & & \multicolumn{3}{|l|}{ Copepods } \\
\hline $29 / 09 / 00$ & 24 & Sapphirina spp. (1) & 13.15 & 4.72 \\
\hline $30 / 10 / 00$ & 26 & Sapphirina spp. (2) & 7.04 & 4.72 \\
\hline 19/08/01 & 28 & Pleuromamma xiphias (2) & 1.90 & 6.14 \\
\hline 16/08/01 & 28 & Mixed euphausiids & 1.86 & 7.52 \\
\hline 16/08/01 & 28 & \multicolumn{2}{|l|}{ Amphipod } & 2.22 \\
\hline 16/08/01 & 28 & \multicolumn{3}{|l|}{ Polychaete worm } \\
\hline $17 / 08 / 01$ & 28 & Colonial radiolaria & $10.70(1.07)$ & - \\
\hline & & \multicolumn{3}{|l|}{ Colonial cyanobacteria } \\
\hline $29 / 09 / 00$ & 24 & Trichodesmium spp. (2) & $28.57(0.32)$ & $9.52(0.02)$ \\
\hline $30 / 10 / 00$ & 26 & Trichodesmium spp. (3) & $12.50(0.14)$ & $0.00(0.00)$ \\
\hline $15 / 08 / 01$ & 28 & Trichodesmium spp. (4) & $7.14(0.08)$ & $0.00(0.00)$ \\
\hline $15 / 08 / 01$ & 28 & Trichodesmium spp. (5) & $3.57(0.04)$ & $0.00(0.00)$ \\
\hline
\end{tabular}

ranged from 0.72 (amphipods) to 13.15 (copepods) $\mu \mathrm{g} \mathrm{C}$ $\mathrm{mg}$ body $\mathrm{C}^{-1} \mathrm{~h}^{-1}$. Radiolaria colonies produced $10.7 \mu \mathrm{g} \mathrm{C}$ mg colony $\mathrm{C}^{-1} \mathrm{~h}^{-1}$ (or ca. $1 \mu \mathrm{g} \mathrm{C}$ colony ${ }^{-1} \mathrm{~h}^{-1}$ ), and Trichodesmium colonies produced 3.57 to $28.57 \mu \mathrm{g} \mathrm{C} \mathrm{mg}$ colony $\mathrm{C}^{-1} \mathrm{~h}^{-1}$ (or 0.04 to $0.32 \mu \mathrm{g} \mathrm{C}$ colony ${ }^{-1} \mathrm{~h}^{-1}$ ). Ammonia excretion for crustaceans ranged from 2.22 (amphipods) to 7.52 (euphausiids) $\mu \mathrm{g} \mathrm{N}$ mg body $\mathrm{N}^{-1} \mathrm{~h}^{-1}$. The relatively large polychaeate worms excreted $6.19 \mu \mathrm{g}$ $\mathrm{N}$ mg body $\mathrm{N}^{-1} \mathrm{~h}^{-1}$, and in 3 out of 4 experiments Trichodesmium colonies produced no ammonia.

\section{CDOM absorption signatures and production rates}

The different major groups of plankton appear to have diagnostic absorption spectra; the CDOM production varied in magnitude but the shape of the curve was similar within different major groups of zooplankton. (Note: absorption and production are used interchangeably in the following discussion, as CDOM production is simply the absorption spectra normalized to animal density, weight, and time.) The CDOM absorp-

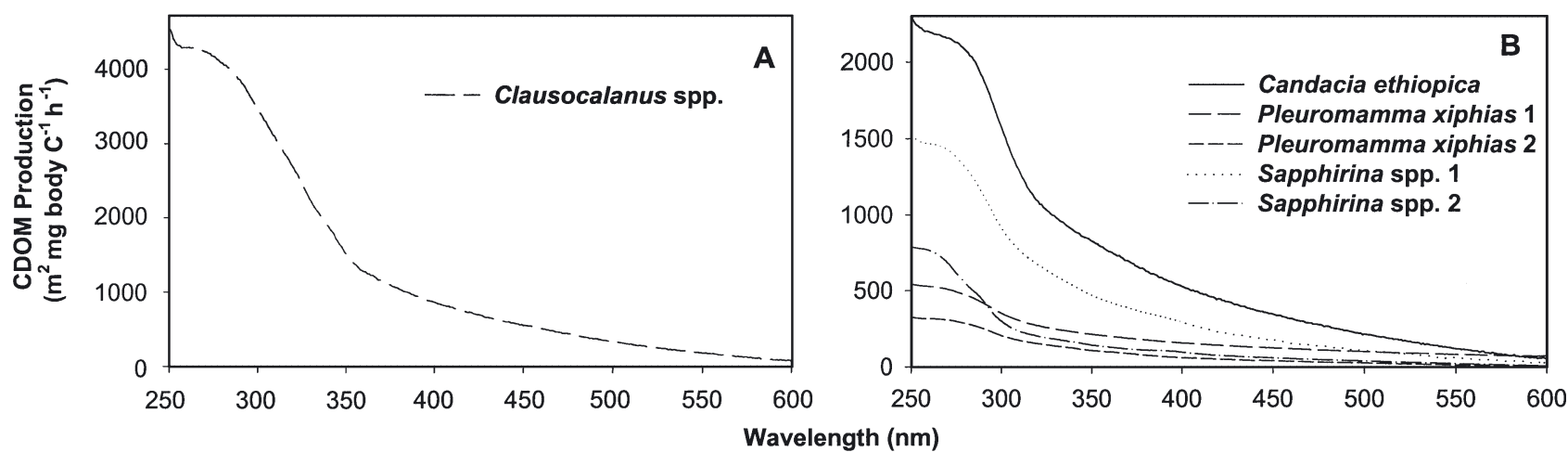

Fig. 2. Chromophoric (or colored) dissolved organic matter (CDOM) production by Sargasso Sea copepods. Control absorption spectra (filtered seawater [FSW] + tow water) have already been subtracted. All incubations were carried out in $0.2 \mu \mathrm{m}$ FSW for $\sim 8 \mathrm{~h}$ in the dark. CDOM production is the increase in the CDOM absorption coefficient normalized to the density and weight of organisms in the experiment and time (see 'Materials and methods'). Weights (mg body $\mathrm{C}$ ind. ${ }^{-1}$ ), were determined as follows: Clausocalanus spp. (0.01), Candacia ethiopica (0.04) (from Verity 1985); Pleuromamma xiphias (0.22; from Steinberg et al. 2000, 2002), Sapphirina spp. (0.05; body volume to C conversion) 


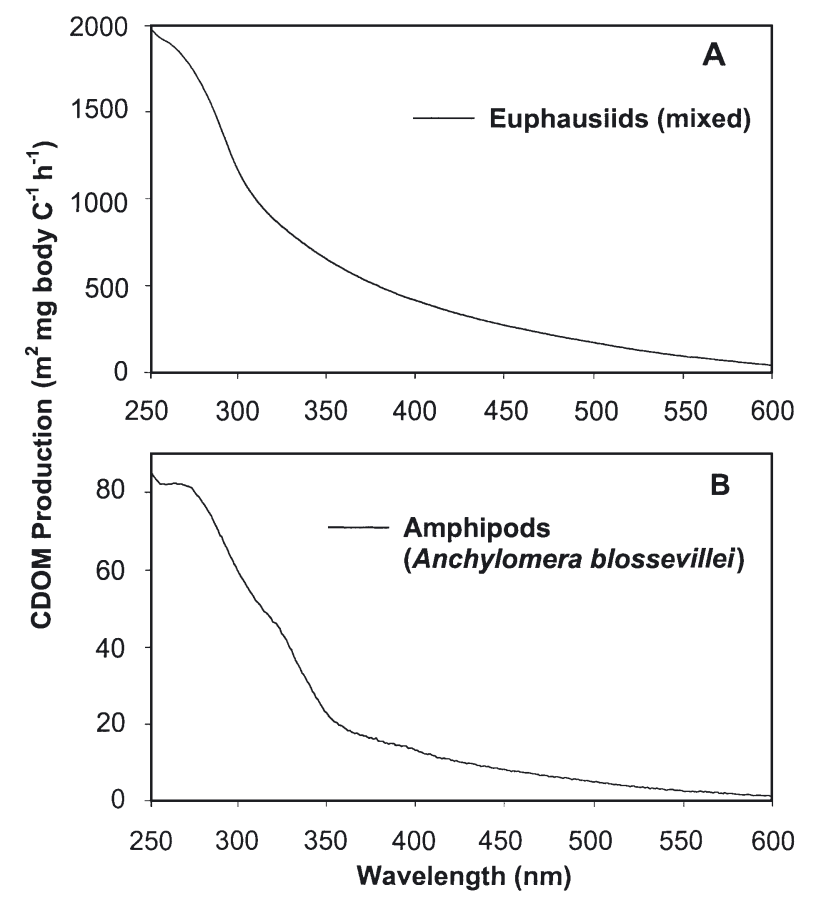

Fig. 3. Chromophoric (or colored) dissolved organic matter (CDOM) production by other crustaceans. (A) Euphausiids (mixed species including: Euphausiia hemigibba, Thysanopoda aequlais, and E. brevis), (B) amphipod Anchylomera blossevillei. Control absorption spectra (filtered seawater $[\mathrm{FSW}]+$ tow water) have already been subtracted. All incubations were carried out in $0.2 \mu \mathrm{m}$ FSW for $\sim 8 \mathrm{~h}$ in the dark. CDOM production is the increase in the CDOM absorption coefficient normalized to the density and weight of organisms in the experiment and time (see 'Materials and methods'). Weights (mg body $\mathrm{C}_{\text {ind }}{ }^{-1}$ ) for mixed euphausiids (1.26) and A. blossevillei (1.66) were determined in previous experiments (Steinberg et al. 2000, 2002)

tion spectra found for crustacean zooplankton are shown in Figs. 2 \& 3. All copepod species tested are common epipelagic copepods in the Sargasso Sea, with the exception of Pleuromamma xiphias, which is a vertical migrator and only found within the top $200 \mathrm{~m}$ at night. The euphausiids and amphipods are also vertical migrators. The peak absorption for a variety of copepods tested, as well as for amphipods and euphausiids, is in the UV range between 250 and $275 \mathrm{~nm}$, with a steady decline thereafter. (Higher absorption may have occurred at wavelengths $<250 \mathrm{~nm}$; however, for simplicity we refer to 'areas of maximum absorbance' or 'peaks' occurring in the wavelengths routinely measured for CDOM.) The smallest copepods, Clausocalanus spp., had the highest weight-specific CDOM excretion rates of the crustacea (peak ca. $4400 \mathrm{~m}^{2} \mathrm{mg}$ body $\mathrm{C}^{-1} \mathrm{~h}^{-1}$ ). The relatively large amphipods had significantly lower excretion rates (peak ca. $85 \mathrm{~m}^{2} \mathrm{mg}$ body $\mathrm{C}^{-1} \mathrm{~h}^{-1}$ ) than the copepods (peak ca. 325 to $4400 \mathrm{~m}^{2} \mathrm{mg}$ body $\mathrm{C}^{-1} \mathrm{~h}^{-1}$ ) and euphausiids (peak ca. $2000 \mathrm{~m}^{2} \mathrm{mg}$ body $\mathrm{C}^{-1} \mathrm{~h}^{-1}$ ).
The shape of the CDOM absorption spectra was different for gelatinous zooplankton. A large peak in absorption was observed in each of 3 species of salps (pelagic tunicates) between 295 and $298 \mathrm{~nm}$ (Fig. 4). The Salpa fusiformis CDOM production (peak ca. $2500 \mathrm{~m}^{2}$ mg body $\mathrm{C}^{-1} \mathrm{~h}^{-1}$; Fig. 4A) was considerably higher than the other 2 salp species (peaks ca. 430 and $610 \mathrm{~m}^{2} \mathrm{mg}$ body $\mathrm{C}^{-1} \mathrm{~h}^{-1}$; Fig. 4B). The spectra from 2 alciopid worm (a gelatinous polychaete) experiments exhibited an absorption peak at $270 \mathrm{~nm}$, with a second peak at $425 \mathrm{~nm}$ in 1 experiment (Naiades sp. 1) (Fig. 5), with CDOM production peaks ca. 350 and $400 \mathrm{~m}^{2} \mathrm{mg}$ body $\mathrm{C}^{-1} \mathrm{~h}^{-1}$. The salps and alciopid worms used in our experiments vertically migrate; however, the salps $S$. fusiformis and Iasis zonaria also occur in the top $200 \mathrm{~m}$ during the day in the Sargasso Sea (Madin et al. 1996, D. K. Steinberg pers. obs.). Colonial radiolarians form a gelatinous matrix secreted by the individual cells and these gelatinous colonies are conspicuous members of the surface plankton during the summer in the Sargasso Sea and ubiquitous in temperate, subtropical, and tropical oceanic environments (Swanberg \& Harbison 1980, Swanberg 1983). The absorption spectra for the colonial radiolarians (Fig. 6), with a

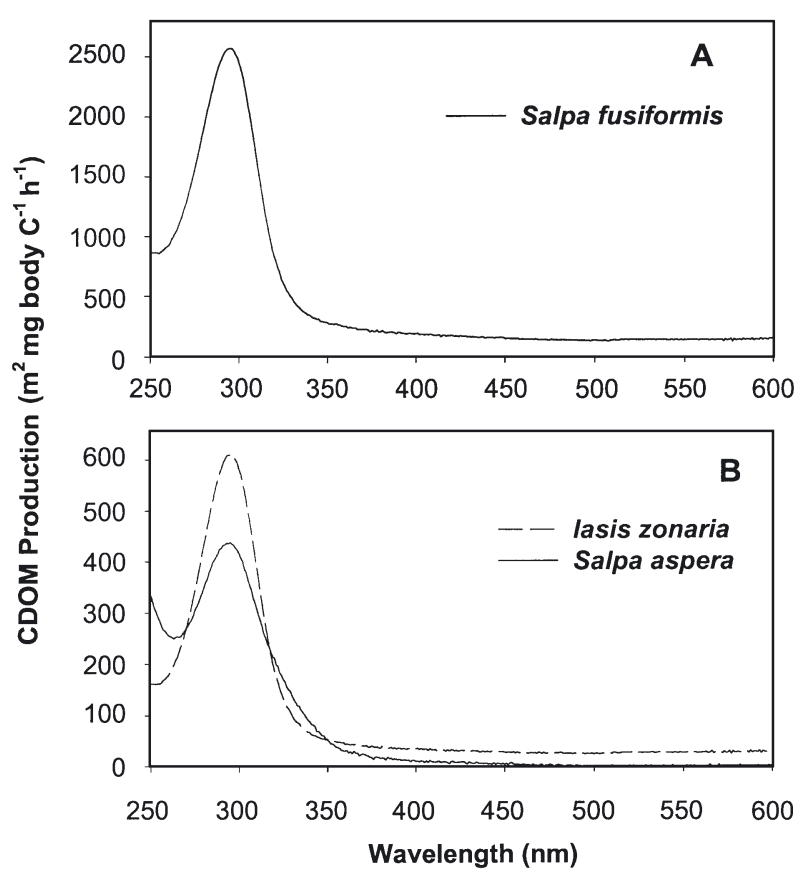

Fig. 4. Chromophoric (or colored) dissolved organic matter (CDOM) production by salps. Control absorption spectra (filtered seawater [FSW] + tow water) have already been subtracted. All incubations were carried out in $0.2 \mu \mathrm{m}$ FSW for $\sim 8 \mathrm{~h}$ in the dark. CDOM production is the increase in the CDOM absorption coefficient normalized to the density and weight of organisms in the experiment and time (see 'Materials and methods'). Weights (mg body C ind. ${ }^{-1}$ ) for Salpa fusiformis (1.81), Iasis zonaria (1.72), and $S$. aspera (0.82) were determined using algorithms in Madin \& Deibel (1998) 


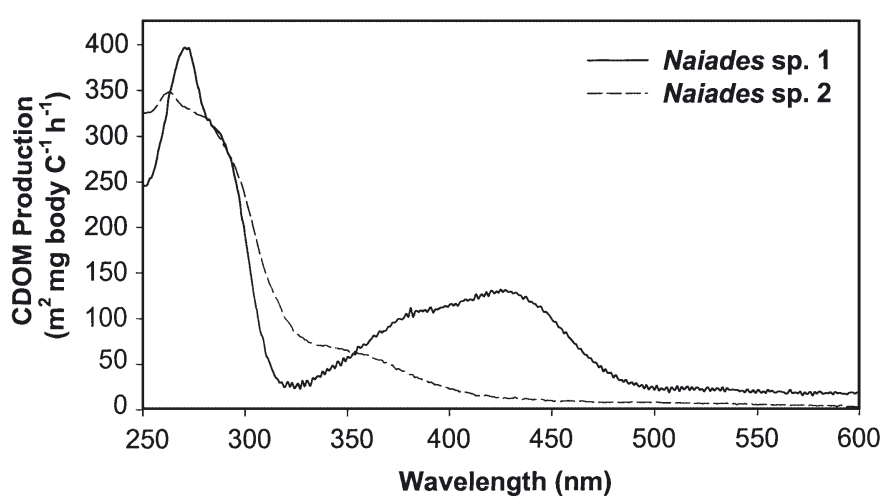

Fig. 5. CDOM production by alciopid worms (gelatinous polychaetes) Naiades spp. Control absorption spectra (FSW + tow water) have already been subtracted. All incubations were carried out in $0.2 \mu \mathrm{m}$ FSW for $\sim 8 \mathrm{~h}$ in the dark. CDOM production is the increase in the CDOM absorption coefficient normalized to the density and weight of organisms in the experiment and time (see 'Materials and methods'). Animal dry weights were measured in this experiment and converted to $\mathrm{C}$ as described in Table 2. Weights (mg body $\mathrm{C}$ animal ${ }^{-1}$ ) are Naiades sp. 1 (7.61) and sp. 2 (3.00)

large peak in absorption at $300 \mathrm{~nm}$, was very similar to that for the salps (Fig. 4). Production of CDOM was higher for the radiolaria than any other organism tested (peak ca. $23000 \mathrm{~m}^{2} \mathrm{mg}$ colony $\mathrm{C}^{-1} \mathrm{~h}^{-1}$ or $2300 \mathrm{~m}^{2}$ colony $^{-1} \mathrm{~h}^{-1}$; Fig. 6).

CDOM absorption spectra for the colonial cyanobacteria Trichodesmium sp. are shown in Fig. 7. We chose this species to test for CDOM production as it is ubiquitous in the surface waters of the Sargasso Sea and is especially abundant in summer and late fall. Although to different degrees, Trichodesmium in all experiments

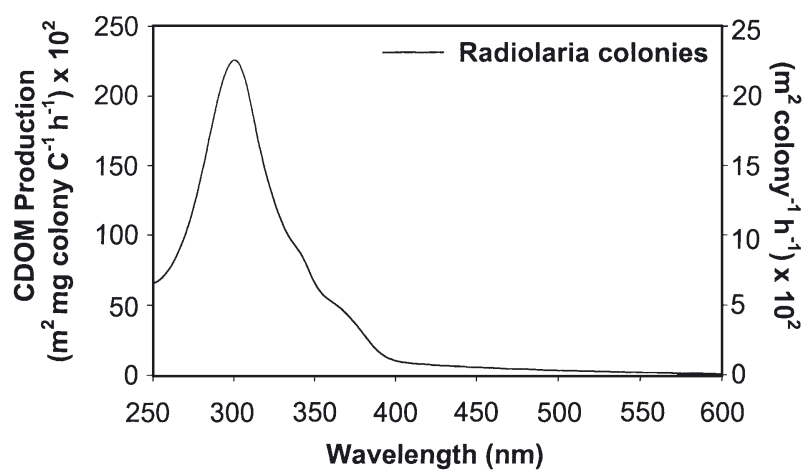

Fig. 6. Chromophoric (or colored) dissolved organic matter (CDOM) production by colonial radiolaria. Control absorption spectra (filtered seawater [FSW] + tow water) have already been subtracted. All incubations were carried out in $0.2 \mu \mathrm{m}$ FSW for $\sim 8 \mathrm{~h}$ in the dark. CDOM production is the increase in the CDOM absorption coefficient normalized to the density and weight of organisms in the experiment and time (see 'Materials and methods'). Colony weight (0.1 $\mathrm{mg} \mathrm{C}$ colony $^{-1}$ ) from Swanberg (1983) produced CDOM with absorption peaks at $\sim 325 \mathrm{~nm}$ and again at $360 \mathrm{~nm}$. Peak per-colony production of CDOM for Trichodesmium ranged from ca. 890 to $4460 \mathrm{~m}^{2} \mathrm{mg}$ colony $\mathrm{C}^{-1} \mathrm{~h}^{-1}$ or 10 to $50 \mathrm{~m}^{2}$ colony $^{-1} \mathrm{~h}^{-1}$ (Fig. 7). The wavelengths of maximum absorption for all major taxa of plankton are summarized in Table 3.

\section{DISCUSSION}

\section{Production of CDOM by zooplankton and Trichodesmium}

CDOM was produced by a variety of zooplankton taxa as well as by the colonial cyanobacteria Trichodesmium. Absorption spectra from filtered seawater, and from the water in which zooplankton were collected, were consistently lower than treatments containing animals. The addition to the controls of some CDOM present in whole tow water (see 'Materials and methods') occasionally produced slightly higher absorption coefficients than $0.2 \mu \mathrm{m}$ FSW, and thus likely affected the absorption coefficient values of some of the treatments. However, this did not change the shape of the spectra, with the exception of 2 incubations with Trichodesmium (Tricho-1, Tricho-2; Fig. 7). These 2 incubations produced a higher absorption coefficient and slightly different absorption spectra shape for Trichodesmium due to the relatively lower CDOM absorption in the controls.

Most of the CDOM measured in the zooplankton experiments was likely excretory. Other possible sources of DOM from zooplankton include leaching from fecal pellets (e.g. Urban-Rich 1999), sloppy feeding while

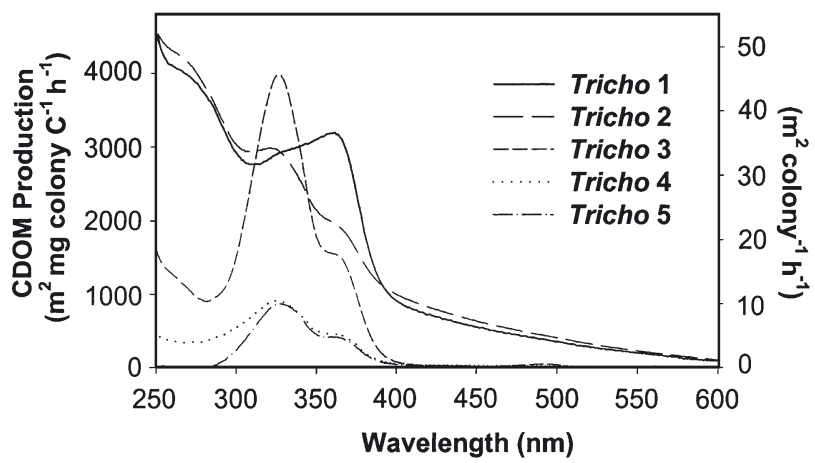

Fig. 7. Chromophoric (or colored) dissolved organic matter (CDOM) production by colonies of the cyanobacterium Trichodesmium spp. Control absorption spectra (filtered seawater [FSW] + tow water) have already been subtracted. All incubations were carried out in $0.2 \mu \mathrm{m}$ FSW for $\sim 8 \mathrm{~h}$ in the dark. CDOM production is the increase in the CDOM absorption coefficient normalized to the density and weight of organisms in the experiment and time (see 'Materials and methods'). Colony weight (0.011 $\mathrm{mg} \mathrm{C}$ colony $^{-1}$ ) from Carpenter (1983) 
Table 3. Wavelengths of maximum absorption for major taxa of plankton

\begin{tabular}{|lc|}
\hline Taxon & $\begin{array}{c}\text { Wavelength(s) of } \\
\text { maximum absorption (nm) }\end{array}$ \\
\hline Crustacea & $250-275$ \\
Copepods & \\
Euphausiids & \\
Amphipods & $295-298$ \\
Salps (pelagic tunicates) & 270,425 \\
Gelatinous polychaete (alciopid) & 300 \\
worm & 325,360 \\
Colonial radiolaria & \\
Colonial cyanobacteria & (Trichodesmium spp.) \\
\hline
\end{tabular}

handling prey (Dagg 1974, Lampert 1978, Jumars et al. 1989), and seepage from dead carcasses (Lee \& Fisher 1992). No CDOM signal was detected in fecal pellet leaching experiments. Thus while some leaching of CDOM from feces likely occurs, it is insignificant compared to excretion, as has been found for comparisons of DOC excretion and DOC leaching from fecal pellets for a variety of vertically migrating zooplankton in the Sargasso Sea (Steinberg et al. 2000). As experiments were conducted in filtered seawater, herbivorous sloppy feeding was likely not a source of CDOM. Sloppy feeding from animals preying on each other (Dagg 1974) is another possibility; however, all animals were counted at the start and end of experiments to account for any discrepancies. Numbers occasionally differed at the start and end of some copepod treatments, but the discrepancy was only a few animals and more likely due to errors in counting than feeding. Since all animals appeared in good condition (actively swimming) at the end of the experiments, seepage from dead carcasses was likely not a source of CDOM, but certainly could be in the water column.

The rate of weight-specific CDOM production was, as expected, generally higher amongst the smaller organisms (e.g. small copepods). The relatively low CDOM production by the hyperiid amphipod Anchylomera blossevillei, which is similar in size to the euphausiids (see Table 2 for weights), could be due to differences in the animals' diet (hyperiid amphipods are carnivorous while euphausiids are omnivorous) and previous feeding history. As CDOM is only a fraction of the total DOM excreted by zooplankton, and in order to observe a measurable CDOM signal, densities of organisms were relatively higher in experimental bottles than in nature. Some density effects on nutrient excretion rates of zooplankton have been reported, although these effects have typically occurred at stocking densities several orders of magnitude higher than those used in our experiments (see Ikeda et al. 2000 and references therein). Although the higher densities could affect excretion rates, it is unlikely a large source of error in our experiments as excretion rates of DOC and $\mathrm{NH}_{4}$ were comparable to previous experiments (Steinberg at al. 2000, 2002) using lower densities of the same species (see section below).

\section{Rates of DOC and $\mathrm{NH}_{4}$ excretion/production}

Rates of DOC and $\mathrm{NH}_{4}$ excretion in our experiments were similar to mean rates measured in previous experiments of excretion of DOC and $\mathrm{NH}_{4}$ by zooplankton in the Sargasso Sea (Steinberg et al. 2000, 2002). For example, DOC excretion by Pleuromamma xiphias of $1.9 \mu \mathrm{g} \mathrm{C} \mathrm{mg} \mathrm{body} \mathrm{C}^{-1} \mathrm{~h}^{-1}(0.68 \mu \mathrm{g} \mathrm{C} \mathrm{mg}$ dry weight $\left.[\mathrm{dwt}]^{-1} \mathrm{~h}^{-1}\right)$ at $28^{\circ} \mathrm{C}$ is similar to rates of $2.6 \pm$ $0.78 \mu \mathrm{g} \mathrm{C}$ mg body $\mathrm{C}^{-1} \mathrm{~h}^{-1}\left(0.93 \pm 0.28 \mu \mathrm{g} \mathrm{C} \mathrm{mg} \mathrm{dwt}{ }^{-1}\right.$ $\mathrm{h}^{-1}$ ) at (mean $\left.\pm 1 \mathrm{SD}\right) 26^{\circ} \mathrm{C}$ found in Steinberg et al. (2000). For the same copepod, rates of $\mathrm{NH}_{4}$ excretion are also comparable $\left(6.14 \mu \mathrm{g} \mathrm{N}\right.$ mg body $\mathrm{N}^{-1} \mathrm{~h}^{-1}$, or $0.43 \mu \mathrm{g} \mathrm{N} \mathrm{mg} \mathrm{dwt} \mathrm{t}^{-1} \mathrm{~h}^{-1}$ in the current study vs $5.95 \pm$ $0.14 \mu \mathrm{g} \mathrm{N}$ ind. ${ }^{-1} \mathrm{~h}^{-1}$, or $0.42 \pm 0.01 \mu \mathrm{g} \mathrm{N} \mathrm{mg} \mathrm{dwt} \mathrm{t}^{-1} \mathrm{~h}^{-1}$ in Steinberg et al. 2002). Rates of DOC and $\mathrm{NH}_{4}$ excretion for the larger amphipods and euphausiids (Table 2) are also very similar to previous results at similar temperatures (Steinberg et al. 2000, 2002). To our knowledge, these are the first reported rates of DOC production by colonial radiolaria or Trichodesmium colonies. Likely any DOC produced was due to leaching from the colony matrix (see section below), or possibly excretion by associated protozoa (e.g. Sheridan et al. 2002).

\section{Taxa-specific CDOM excretion signatures and possible composition}

The different taxa of zooplankton and protozoa, as well as Trichodesmium, appear to have diagnostic absorption spectra. The CDOM absorption spectra typical for crustacean zooplankton are in the UV between 250 and $275 \mathrm{~nm}$, with a steady decline thereafter. As most of the CDOM produced is likely by excretion, we can speculate as to what comprises the excretion products. Dissolved organic nitrogen (e.g. urea, amino acids) can be excreted at substantial levels, ranging from 7 to $89 \%$ of the total $\mathrm{N}$ excreted for a variety of zooplankton taxa (see Table 3 in Steinberg et al. 2002 for review), frequently exceeding ammonia as the primary nitrogenous excretory product (e.g. Conover \& Gustavson 1999, Miller \& Glibert 1999). Little is known about the components making up DOC excreted by zooplankton, but a substantial fraction appears to be carbohydrates (C. A. Carlson \& D. K. Steinberg unpubl.). Of the known naturally occurring dissolved organic 
compounds in seawater-including free and combined amino acids, free and combined sugars, fatty acids, sterols, vitamins, aliphatic hydrocarbons, urea and uronic acids - most have their maximum wavelength of significant absorption below $300 \mathrm{~nm}$ (Zika 1981). Thus, it is not surprising that CDOM excreted by crustacea exhibits a maximum wavelength of absorption in this area.

The absorption spectra for gelatinous zooplankton and gelatinous radiolarian colonies differed significantly from the crustaceans, with a single absorption peak in the UV region of the spectrum of ca. $300 \mathrm{~nm}$ for salps and radiolarian colonies. Some of the radiolarian colonies became disassociated during the incubation, and it is possible that their high CDOM production rate is due to some dissolution of the mucus holding the colonies together. The gelatinous alciopid worms exhibited absorption peaks in the UV at $270 \mathrm{~nm}$ and in the visible region at $425 \mathrm{~nm}$. These worms produce a visible yellow slime when disturbed (D. K. Steinberg pers. obs.). Although they were not disturbed in the experiments, seepage of this material may normally occur in small amounts from these animals, and is what we detected optically. It is largely the uncharacterized fraction of DOM that is the principal light absorber in the near-UV and visible region of the spectrum, and the chromophoric character of this fraction is thought to be, at least in part, due to plankton by-products (Zika 1981).

Trichodesmium also has its own characteristic absorption spectra with a primary peak at $325 \mathrm{~nm}$ and a secondary peak, or 'shoulder', at $360 \mathrm{~nm}$. These peaks are consistent with mycosporine-like amino acids (MAAs) produced by Trichodesmium. Direct release of UV-absorbing MAAs has been demonstrated previously for Trichodesmium (Subramaniam et al. 1999) and for the coastal red-tide-forming dinoflagellate Lingulodinuium polyedra (Vernet \& Whitehead 1996, Whitehead \& Vernet 2000). Subramaniam et al. (1999) noted strong UV absorption at 332 and $362 \mathrm{~nm}$ for water-soluble pigments from Trichodesmium. Likewise, an increase in absorption at $330 \mathrm{~nm}$ with a 'shoulder' at $360 \mathrm{~nm}$ in the absorption spectra was noted for L. polyedra (Vernet \& Whitehead 1996, Whitehead \& Vernet 2000). This absorption spectrum corresponds to the absorption spectra measured for MAAs (Vernet \& Whitehead 1996, Whitehead \& Vernet 2000). MAAs are thought to be the major class of UV absorbing compounds in the marine environment (Bandaranayake 1998, Shick \& Dunlap 2002), and important in the attenuation of UV radiation. These compounds are found in a wide range of marine organisms (including phytoplankton and zooplankton) and may provide photoprotection from, or minimize deleterious effects of UV radiation (Karentz et al. 1991, Bandaranayake 1998, Jeffrey et al. 1999, Karentz 2001, Shick \& Dunlap 2002).
Enhanced UV absorption in the summer stratified surface waters of the Sargasso Sea is likely caused by an increase in MAA production by phytoplankton (Morrison \& Nelson 2004). As Trichodesmium is ubiquitous in the surface waters of tropical and subtropical seas (Carpenter \& Price 1977, Capone et al. 1997, Dupouy et al. 2000), this species could play an important role in CDOM dynamics and absorption of UV radiation. Likewise, the excretion of CDOM into the water column by zooplankton may have the beneficial effect of decreasing UV transmission, and thus providing photoprotection for zooplankton against harmful UV radiation, as release of MAAs are considered to do for phytoplankton (Vernet \& Whitehead 1996).

Could CDOM be used as an indicator of plankton present in the water column? The absorption spectra, such as those typical for the crustacea, are similar in shape to background CDOM (e.g. compare control spectra with that of the copepod in Fig. 1). Other absorption spectra, such as those typical for some of the gelatinous zooplankton or Trichodesmium, are quite distinctive, and peaks or 'shoulders' in the 'average' CDOM spectra at their wavelength of maximum absorption may be evidence of the presence of these organisms in the water column. We sampled during some Trichodesmium blooms, and controls of the surrounding water column did occasionally exhibit absorption with a slight 'shoulder' at $360 \mathrm{~nm}$. This may indicate that taxa-specific signals are not necessarily diluted too quickly from the background, and thus might be detectable. Many gelatinous zooplankton, such as salps, are found in dense swarms or 'blooms' (Andersen 1998), and it is possible their characteristic CDOM signature could be detected during blooms as well. Other possibilities include using CDOM fluorescence signatures. A fraction of the absorbing chromophores that make up CDOM are also fluorescent. These have been used to provide a 'fingerprint' of copepod and larvacean feeding (McCarty \& Urban-Rich 2003, UrbanRich unpubl.), analogous to how fluorescent fingerprints have been used for discriminating between terrestrial versus marine sources of fluorescent $\mathrm{CDOM}$, and different oceanic water masses (Coble et al. 1990, 1998, Del Castillo et al. 1999, 2000).

\section{Possible role and consequences of plankton production of CDOM}

\section{Secondary effects of zooplankton DOM release}

As described above, zooplankton can directly release $\mathrm{CDOM}_{;}$however, there are also secondary effects associated with zooplankton CDOM/DOM release. Release of DOM by zooplankton can be a source of substrate for 
both bacterial growth and CDOM production by bacteria. Bacteria can process labile DOM into more refractory forms, so they are potentially both a sink for labile DOM or CDOM and a source for refractory DOM or CDOM. Preliminary experiments have demonstrated that bacterioplankton concentration increases an order of magnitude over $60 \mathrm{~h}$ in the presence of zooplankton excretia, indicating that a portion of zooplanktonexcreted DOM is a highly labile substrate for bacterial metabolism. Nelson et al. (in press) demonstrated that CDOM was produced as a byproduct of remineralization of labile DOM by heterotrophic prokaryotes. In their experiments, comparisons between remineralization of simple substrates (i.e. glucose) versus complex substrates (i.e. zooplankton excretia) showed that the complex nature of the substrate played a role in the persistence of the CDOM byproduct. CDOM was produced in both the glucose-amended and zooplankton excretia-amended treatments, but only in the zooplankton excretia treatments did net CDOM persist longer than 1 wk (Nelson et al. in press). Thus, zooplankton produce CDOM both directly by excretion, and indirectly as a byproduct of remineralization of freshly released DOM. These results have important implications for the net CDOM signal observed in the Sargasso Sea every year.

\section{Significance for the Sargasso Sea CDOM cycle}

Results from a multi-year time series of CDOM in the Sargasso Sea at the BATS station indicate a generally homogenous distribution of CDOM throughout the well-mixed water column in the winter. This changes to a distinct surface-minimum, subsurface-maximum pattern in the stratified summer water column (Nelson et al. 1998, Nelson \& Siegel 2002). This cycle is a consequence of a number of production and removal processes. The summer profile reflects the combined effects of sunlight-mediated bleaching and microbial consumption of CDOM near the surface, and subsurface production of CDOM (Nelson et al. 1998, Nelson \& Siegel 2002). However, there is little or no correlation between DOC concentration or primary productivity, and CDOM concentration or production rate in the Sargasso Sea (Nelson et al. 1998). The subsurface production of CDOM in the summer typically occurs shallower $(50$ to $100 \mathrm{~m}$ ) than the deep chlorophyll maximum layer (80 to $120 \mathrm{~m}$ ), and is not at a depth of high phytoplankton biomass or productivity. The layer of CDOM production does, however, correlate well with the layer of highest bacterial biomass and production (Carlson et al. 1996), suggesting bacteria are an important source of the CDOM. Experiments confirm that the microbial community, acting on substrates such as natural DOC, zooplankton excretia, or algal exudates, can produce CDOM, which can be consumed by bacteria but can also persist (Nelson et al. in press).

What role might zooplankton play in this cycle? We have demonstrated release of DOM by zooplankton excretion in a variety of taxa. This excretia may serve as an important source of labile DOM supporting instantaneous bacterial production. Carlson et al. (unpubl.) have demonstrated that semi-labile DOM, which accumulates at the BATS station, appears to resist rapid microbial degradation by surface microbial assemblages. They concluded that instantaneous bacterial production is supported by the tight coupling between DOM production mechanisms such as algal release and zooplankton excretion, rather than from standing stocks of semi-labile DOC. Thus, DOM production by zooplankton (Steinberg et al. 2000, 2002), and its subsequent remineralization by bacteria, could be an important production source of persistent CDOM in oceanic systems (Nelson et al. in press). Excretion of labile DOM by zooplankton could be a direct source or a substrate for bacterial CDOM production, even in the absence of a spring bloom. In addition, vertically migrating zooplankton in the Sargasso Sea excrete a significant amount of DOM below the mixed layer (Steinberg et al. 2000, 2002). Several of the species of zooplankton demonstrated to excrete CDOM in our experiments are vertical migrators, and could contribute to patterns of elevated CDOM concentrations at depth, as seen in the Sargasso Sea and many other oceanic environments (Nelson \& Siegel 2002).

\section{Conclusions and future prospects}

We have demonstrated direct release of chromophoric organic compounds by a broad range of oceanic plankton taxa, most of which have not been previously reported to do so. These different major taxa appear to produce characteristic absorption spectra. While the purpose of this release remains unclear, the fact that we rarely observe the characteristic absorption peaks in field CDOM spectra, other than perhaps in bloom conditions, suggests CDOM produced by plankton is labile and consumed rapidly via bleaching or microbial consumption. Over the longer term we suggest that the released compounds act as a substrate for the production of longer-lived CDOM. Thus, much of the CDOM produced by plankton is remineralized, or becomes refractory CDOM due to microbial reprocessing. Future studies will be needed on the composition of biologically produced CDOM and its potential role in UV photoprotection. The mechanisms of biological production of CDOM are important in the cycling of CDOM in the Sargasso Sea and, presumably, other parts of the world's oceans. 
Acknowledgements. Many thanks to the captain, crew, and marine technicians of RV 'Weatherbird II' for help with sample collection. We greatly appreciate technical assistance given by M. Ranelletti, S. Goldberg, K. Paterson, A. Scott, and S. Wilson. Thanks also to B. Morris and J. McCarty for assistance at sea. This work was funded by NSF OCE-9977399.

\section{LITERATURE CITED}

Andersen V (1998) Salp and pyrosomid blooms and their importance in biogeochemical cycles. In: Bone Q (ed) The biology of pelagic tunicates. Oxford University Press, New York, p 125-137

Bandaranayake WM (1998) Mycosporines: are they nature's sunscreens? Nat Prod Rep 15:159-172

Capone DG, Zehr JP, Paerl HW, Bergman B, Carpenter EJ (1997) Trichodesmium, a globally significant marine cyanobacterium. Science 276:1221-1229

Carlson CA, Ducklow HW, Sleeter TD (1996) Stocks and dynamics of bacterioplankton in the northwestern Sargasso Sea. Deep-Sea Res II 43:491-516

Carpenter EJ (1983) Physiology and ecology of marine planktonic Oscillatoria (Trichodesmium). Mar Biol Lett 4:69-85

Carpenter EJ, Price CC (1977) Nitrogen fixation, distribution, and production of Oscillatoria (Trichodesmium) spp. in the western Sargasso and Caribbean Seas. Limnol Oceanogr 22:60-72

Coble PG, Green SA, Blough NF, Gagosian RB (1990) Characterization of dissolved organic matter in the Black Sea by fluorescence spectroscopy. Nature 348:432-435

Coble PG, Del Castillo CE, Avril B (1998) Distribution and optical properties of CDOM in the Arabian Sea during the 1995 Southwest Monsoon. Deep-Sea Res II 45:2195-2223

Conover RJ, Gustavson KR (1999) Sources of urea in Arctic seas: zooplankton metabolism. Mar Ecol Prog Ser 179: $41-54$

Dagg MJ (1974) Loss of prey body contents during feeding by an aquatic predator. Ecology 5:903-906

Del Castillo CE, Coble PG, Morel JM, Lopez JM, Corredor JE (1999) Analysis of the optical properties of the Orinoco River plume by absorption and fluorescence spectroscopy. Mar Chem 66:35-51

Del Castillo CE, Gilbes F, Coble PG, Muller-Karger FE (2000) On the dispersal of riverine colored dissolved organic matter over the West Florida Shelf. Limnol Oceanogr 45: 1425-1432

Dupouy C, Neveux J, Subramaniam A, Mullohand M, Montoya JP, Campbell L, Carpenter EJ, Capone DG (2000) Satellite captures Trichodesmium blooms in the southwestern tropical Pacific. EOS Trans AGU 81:13-20

Green SA, NV Blough (1994) Optical absorption and fluorescence properties of chromophoric dissolved organic matter in natural waters. Limnol Oceanogr 39:1903-1916

Hansell DA, Carlson CA (2001) Biogeochemistry of total organic carbon and nitrogen in the Sargasso Sea: control by convective overturn. Deep-Sea Res II 48:1649-1667

Hansson LJ, Norrman B (1995) Release of dissolved organic carbon (DOC) by the scyphozoan jellyfish Aurelia aurita and its potential influence on the production of planktic bacteria. Mar Biol 121:527-532

Hedges JI, Keil RG, Benner R (1997) What happens to terrestrial organic matter in the ocean? Org Geochem 27: 195-212

Herring PJ (1967) The pigments of plankton at the sea surface. Symp Zool Soc Lond 19:215-235

Ikeda T, Torres JJ, Hernandez-Leon S, Geiger SP (2000)
Metabolism. In: Harris RP, Wiebe PH, Lenz J, Skjoldal HR, Huntley M (eds) ICES zooplankton methodology manual. Academic Press, London, p 455-532

Jeffrey SW, MacTavish HS, Dunlap WC, Vesk M, Groenewoud K (1999) Occurance of UV-A- and UV-B-absorbing compounds in 152 species (206 strains) of marine microalgae. Mar Ecol Prog Ser 189:35-51

Johnsen S (2000) Cryptic and conspicuous coloration in the pelagic environment. Proc R Soc Lond B 269:243-256

Johnsen S, Widder EA (2001) Ultraviolet absorption in transparent zooplankton and its implications for depth distribution and visual predation. Mar Biol 138:717-730

Jumars PA, Penry DL, Baross JA, Perry MJ, Frost BW (1989) Closing the microbial loop: dissolved carbon pathway to heterotrophic bacteria from incomplete ingestion, digestion and adsorption in animals. Deep-Sea Res 36:483-495

Karentz D (2001) Chemical defenses of marine organisms against solar radiation exposure: UV-absorbing mycosporine-like amino acids and scytonemin. In: McClintock J, Baker B (eds) Marine chemical ecology. Marine Science Series, CRC Press, Boca Raton, FL, p 481-520

Karentz D, McEuen FS, Land MC, Dunlap WC (1991) Survey of mycosporine-like amino acid compounds in Antarctic marine organisms: potential protection from ultraviolet exposure. Mar Biol 108:157-166

Kieber RJ, Zhou X, Mopper K (1990) Formation of carbonyl compounds from UV-induced photodegradation of humic substances in natural waters: fate of riverine carbon in the sea. Limnol Oceanogr 35:1503-1515

Koroleff F (1983) Determination of ammonia. In: Grasshoff $K_{r}$ Ehrhardt M, Kremling K (eds) Methods of seawater analysis, 2nd edn. Verlag Chemie, Weinheim

Lampert W (1978) Release of dissolved organic carbon by grazing zooplankton. Limnol Oceanogr 23:831-834

Lee BG, Fisher NS (1992) Decompostion and release of elements from zooplankton debris. Mar Ecol Prog Ser 88: $117-128$

Madin LP, Deibel D (1998) Feeding and energetics of Thalacia. In: Bone Q (ed) The biology of pelagic tunicates. Oxford University Press, New York, p 81-103

Madin LP, Kremer P, Hacker S (1996) Distribution and vertical migration of salps (Tunicata, Thalacia) near Bermuda. J Plankton Res 18:747-755

Madin LP, Horgan EF, Steinberg DK (2001) Zooplankton at the Bermuda Atlantic Time-series Study (BATS) station: seasonal and interannual variation in biomass 1994-1998. Deep-Sea Res II 48:2063-2082

McCarty JT, Urban-Rich J (2003) Characterization of chromophoric dissolved organic matter produced during copepod grazing. American Society of Limnology and Oceanography (ASLO) Aquatic Sciences meeting, Salt Lake City, Utah, February 8-14, 2003, meeting abstract book. ASLO Waco, TX

McFall-Ngai MJ (1990) Crypsis in the pelagic environment. Am Zool 30:175-188

Michaels AF, Knap AH (1996) Overview of the US JGOFS BATS and Hydrostation S program. Deep-Sea Res II 43(23):157-198

Michaels AF, Caron DA, Swanberg NR, Howse FA, Michaels CM (1995) Planktonic sarcodines (Acantharia, Radiolaria, Foraminifera) in surface waters near Bermuda: abundance, biomass, and vertical flux. J Plankton Res 17: 131-163

Miller C A, Glibert PM (1999) Nitrogen excretion by the calanoid copepod Acartia tonsa: results of mesocosm experiments. J Plankton Res 20:1767-1780

Mopper K, Kieber DJ (2002) Photochemistry and the cycling 
of carbon, sulfur, nitrogen, and phosphorus. In: Hansell DA, Carlson CA (eds) Biogeochemistry of marine dissolved organic matter. Academic Press, San Diego, p 455-507

Mopper K, Zhou XL, Kieber RJ, Kieber DJ, Sikorski RJ, Jones RD (1991) Photochemical degradation of dissolved organic carbon and its impact on the oceanic carbon cycle. Nature 353:60-62

Morrison JR, Nelson NB (2004) Seasonal cycle of phytoplankton UV absorption at the Bermuda Atlantic Time-series Study (BATS) site. Limnol Oceanogr 49:215-224

Nagata T, Kirchman DL (1992) Release of dissolved organic matter by heterotrophic protozoa: implications for microbial foodwebs. Arch Hydrobiol 35:99-109

Nelson NB, Siegel DA (2002) Chromophoric DOM in the open ocean. In: Hansell DA, Carlson CA (eds) Biogeochemistry of marine dissolved organic matter. Academic Press, San Diego, p 547-578

Nelson NB, Siegel DA, Michaels AF (1998) Seasonal dynamics of colored dissolved material in the Sargasso Sea. Deep-Sea Res I 45:931-957

Nelson NB, Carlson CA, Steinberg DK (in press) Production of chromophoric dissolved organic matter by Sargasso Sea microbes. Mar Chem

Opsahl S, Benner R (1997) Distribution and cycling of terrigenous dissolved organic matter in the ocean. Nature 386 : 480-482

Reeve MR (1980) Large cod-end reservoirs as an aid to the live collection of delicate zooplankton. Limnol Oceanogr 26:577-580

Sheridan CC, Steinberg DK, Kling GW (2002) The microbial and metazoan community associated with colonies of Trichodesmium spp.: a quantitative survey. J Plankton Res 24:913-922

Shick JM, Dunlap WC (2002) Mycosporine-like amino acids and related gadusols: biosynthesis, accumulation, and UV-protective functions in aquatic organisms. Annu Rev Physiol 64:223-262

Siegel DA, Michaels AF (1996) Non-chlorophyll light attenuation in the open ocean: Implications for biogeochemistry and remote sensing. Deep-Sea Res II 43:321-345

Siegel DAA, Michaels F, Sorensen JC, O'Brien M, Hammer MA (1995) Seasonal variability of light availability and

Editorial responsibility: Otto Kinne (Editor),

Oldendorf/Luhe, Germany utilization in the Sargasso Sea. J Geophys Res 100: 8675-8713

Steinberg DK, Carlson CA, Bates NR, Goldthwait SA, Madin LP, Michaels AF (2000) Zooplankton vertical migration and the active transport of dissolved organic and inorganic carbon in the Sargasso Sea. Deep-Sea Res I 47: 137-158

Steinberg DK, Carlson CA, Bates NR, Johnson RJ, Michaels AF, Knap AF (2001) Overview of the US JGOFS Bermuda Atlantic Time-series Study (BATS): a decade-scale look at ocean biology and biogeochemistry. Deep-Sea Res II 48: 1405-1447

Steinberg DK, Goldthwait SA, Hansell DA (2002) Zooplankton vertical migration and the active transport of dissolved organic and inorganic nitrogen in the Sargasso Sea. DeepSea Res I 49:1445-1461

Subramaniam A, Carpenter EJ, Karentz D, Falkowski PG (1999) Bio-optical properties of the marine diazotrophic cyanobacteria Trichodesmium spp. I. Absorption and photosynthetic action spectra. Limnol Oceanogr 44:608-617

Swanberg NR (1983) The trophic role of colonial radiolaria in oligotrophic oceanic environments. Limnol Oceanogr 30: 646-652

Swanberg NR, Harbison GR (1980) The ecology of Collozoum longiforme, sp. nov., a new colonial radiolarian from the equatorial Atlantic Ocean. Deep-Sea Res 27A:715-732

Urban-Rich JL (1999) Release of dissolved organic carbon from copepod fecal pellets in the Greenland Sea. J Exp Mar Biol Ecol 232:107-124

Verity PG (1985) Ammonia excretion rates of oceanic copepods and implications for estimates of primary production in the Sargasso Sea. Biol Oceanogr 3:249-283

Vernet M, Whitehead K (1996) Release of ultraviolet-absorbing compounds by the red-tide dinoflagellate Lingulodinium polyedra. Mar Biol 127:35-44

Whitehead K, Vernet M (2000) Influence of mycosporine-like amino acids (MAAs) on UV-absorption by particulate and dissolved organic matter in La Jolla Bay. Limnol Oceanogr 45:1788-1796

Zika RG (1981) Marine organic photochemistry. In: Duursma EK, Dawson R (eds) Marine organic chemistry. Elsevier, New York, p 299-325

Submitted: June 11, 2003; Accepted: November 4, 2003 Proofs received from author(s): February 5, 2004 